\title{
LUÍS DE CAMÕES NAS ENCRUZILHADAS DE UMA ANTROPOFAGIA LUSA
}

Paulo Braz

\begin{abstract}
RESUMO
É sabido que a noção de antropofagia, em matéria de cultura, em muito ultrapassa a questão modernista brasileira e o contexto literário em que produziu Oswald de Andrade. A lição antropofágica atinge uma dimensão trans-histórica que em muito nos auxilia a compreender o conceito de contemporaneidade, assim como o formula Giorgio Agamben. Assim, este trabalho busca assinalar a contemporaneidade da obra camoniana por meio da deglutiçãa antropofágica do monumento que (apesar) dele foi feito - engendrado por poetas portugueses dos séculos XX e XXI, nomeadamente Jorge de Sena e Manuel de Freitas -, a qual enseja uma leitura de Camóes enquanto poeta.
\end{abstract}

PALAVRAS-CHAVE: Luís de Camões; antropofagia; contemporaneidade.

uando Jorge de Sena, na altura de seu vigésimo quinto ano de estudos dedicados à obra camoniana (precisamente em 1973), publicou, em edição de luxo, o título Camóes dirige-se aos seus contemporâneos ${ }^{1}$, estava a dar azo a um dos mais importantes contributos críticos acerca do poeta de quinhentos. Não deve causar espanto o situar-se em trabalho ficcional

1 O volume consistia de três textos reunidos: o poema que dá título à coletânea, primeiramente incluído na obra-prima Metamorfoses (1963), o conto "Super Flumina Babylonis", antes editado no livro Novas andanças do demônio (1966), e o inédito poema "Camóes na Ilha de Moçambique". 
isto que julgo como o indispensável subsídio de Sena no que diz respeito à sua apreciação valorativa da obra de Camóes. Apesar de sua vasta produção bibliográfica no âmbito ensaístico acerca do poeta, à qual se deve mais que a nossa consideração, é em poesia que o seu olhar crítico dimensiona o amplo alcance de sua leitura revolucionária. Ora, poderíamos aventar uma hipótese muito simples para compreender esta afirmativa: se por um lado o trabalho do ensaísta propóe, sistematicamente, poderosos caminhos de análise, é em seus usos da linguagem poética que vemos incorporado o discurso da crise. E é justamente por meio deste discurso crítico que podemos entrever a contemporaneidade da poesia camoniana, posto que, já no século XVI, era ela afeita à inevitável disjunção entre as palavras e as coisas, assim como às perturbaçóes que a incipiente modernidade começava a manifestar no seio da percepção da unidade do sujeito. Portanto, o que de Sena nos interessa é, sobretudo, o investimento em um olhar que capture esta atualidade de Camóes, a qual se pode perceber no entendimento de que sua escrita só se faz a partir da própria consciência de sua impossibilidade constitutiva. Em outras palavras: de que o exercício da linguagem poética, para o nosso moderno Camóes, se processa enquanto devir.

Apostamos na suposição daquilo que poderíamos designar como de-composição poética, no sentido de que defrontamo-nos, tanto n'Os Lusíadas quanto nas Rimas, com um radical investimento na precariedade da linguagem enquanto mola propulsora dos sentidos. Esta carência reconhecida na obra camoniana é o primeiro passo em direção a uma leitura que deseje redescobrir o poeta enquanto poeta. A proposta deste ensaio se funda, principalmente, na tentativa de perscrutar a contemporaneidade da poesia de Camóes a partir de um viés antropofágico: modo pelo qual se debruçaram sobre a sua obra alguns famintos poetas-leitores do século XX e XXI em Portugal. Aliás, é a partir desta noção de falta que buscaremos determinar uma particular ideia, ainda que filiada às perspectivas oswaldianas, de antropofagia. Poderíamos falar de uma antropofagia à lusitana ${ }^{2}$, na medida em que os interesses do que pretendemos destacar com este estudo jamais estiveram fundamentados sob os

2 Reitero aqui que a antropofagia de Oswald de Andrade, tal como compreendida no modernismo brasileiro, tem propósitos muito particulares dentro do contexto literário do início do século XX. A ideia de devoração da matéria cultural europeia e sua consequente transformação em um objeto outro, híbrido por excelência, posto que deglutido por bocas tropicais, corresponde ao anseio modernista de afirmação de uma cultura brasileira. Como veremos, o suposto caso português atende a demandas de outra ordem. 
preceitos de uma escola literária em Portugal, quanto menos foram instituídos enquanto material de análise teórica para a compreensão dos procedimentos intertextuais que aqui serão abordados.

O caso de Camões é muito peculiar no contexto de sua identificação com a pátria portuguesa. Não se trata apenas de uma questão relacional entre as personae edificadas por toda história e em nome dos mais suspeitos interesses ideológicos e as configurações do imaginário português como nação dilatada por todo o globo terrestre. O fato é que, durante séculos, a imagem do Camóes, brônzeo e monumental, reduziu-se a simbolizar o fantasma de uma cultura imperialista que ele mesmo nunca representou. Tanto é que o Dia de Portugal confunde-se com o Dia de Camóes, ironicamente a data de sua morte, 10 de junho de 1580, instituída como data oficial somente na altura de seu terceiro centenário, em 1880. De lá para cá, e mesmo antes, muitos foram os usos e abusos feitos da imagem do poeta, que, aliás, sempre foi mais louvado como objeto de estatuária que como poeta. Concentramos os nossos esforços na tentativa de determinar o que, com a ajuda da leitura de texto de Eduardo Sterzi ${ }^{3}$, também poderíamos chamar de dialética antropofágica, procedimento que vislumbramos com veemente força atuante na moderna poesia portuguesa, no sentido de desapropriar o épico de louros à cabeça e restituir- lhe a dignidade de poeta, homem entre outros homens. Para tanto é que partimos da situação de Jorge de Sena, em meio à agonizante decadência da ditadura salazarista, que prolongava por já mais de década uma guerra colonial sem sentido algum, e mantinha em atraso político e econômico a nação que, na periferia da Europa, enfim precisava assumir a sua contraditória condição histórica de gigante apequenado ${ }^{4}$.

Estamos, portanto, não às vésperas de abril de 74 , já que o poema que em breve leremos traz o paratexto que informa a data de composiçáo a qual dista quase dois anos da Revolução dos Cravos ("Ilha de Moçambique,

3 STERZI, Eduardo. Dialética da devoração e devoração dialética. In. Antropofagia hoje? Oswald de Andrade em cena. ROCHA, João Cezar de Castro; RUFINELLI, Jorge (Org.). São Paulo: Editora É, 2011.

4 O incontornável ensaio de Eduardo Lourenço, "Psicanálise mítica do destino português", é exemplar do sentido trágico pelo qual se guiou Portugal através dos séculos. No texto, o ensaísta diagnostica uma espécie de simultâneo complexo de superioridade e inferioridade de que o imaginário cultural português sofre e o qual faz dever à nação um espaço mais consolidado no cenário político internacional de hoje. 
20/07/1972”), mas em momento de flagrante declínio da política fascista que vigorava há décadas em Portugal ${ }^{5}$. Os tempos de mudança estavam por vir e ao menos a intelectualidade portuguesa ocupava-se do exercício de reabilitar a figura de seu maior poeta, na altura, pouco mais do que um tosco instrumento de manobra ideológica da ditadura salazarista. É preciso ter em vista este Camóes para que possamos compreender em sua profundidade o papel subversivo operado pelo Camóes de Sena, o funcionamento daquilo que iremos denominar como devoração antropofágica do mito e sua consequente transformação de tabu em totem. Vamos ao texto:

$$
\begin{aligned}
& \text { É pobre e já foi rica. Era mais pobre } \\
& \text { quando Camóes aqui passou primeiro, } \\
& \text { cheio de livros a cabeça e lendas } \\
& \text { e muita estúrdia de Lisboa reles. } \\
& \text { Quando passados nele os Orientes } \\
& \text { e o amargor dos vis sempre tão ricos, } \\
& \text { aqui ficou (...) (SENA, 2013, p. 649). }
\end{aligned}
$$

Devoração antropofágica: entre a história e o mito, a leitura que se quer mais inteligente da vida e da obra de Luís de Camóes reconhece nos meandros de sua narrativa biográfica as zonas de indiferenciação com a ficção que tornaram possíveis todas as apropriaçóes ideológicas do poeta e que, aqui, podem ser apreendidas para que seja posto em jogo um novo Camóes, revitalizado de mortal humanidade. Moçambique "É pobre e já foi rica. Era mais pobre / quando Camóes aqui passou primeiro"; de fato, o dado histórico não condiz com o relatado pelo sujeito lírico. Moçambique era, já quando Vasco da Gama lá passou primeiro, ponto estratégico de comércio com as comunidades locais e porto seguro para aqueles que empreendiam sua viagem à Índia. A exploraçáo de ouro, marfim e escravos era, se náo negociada, forçada, o que, de qualquer forma, acena não apenas para índices de estruturação política consolidada como para, também, riquezas. Portanto, na altura em que Camóes lá

5 O Estado Novo português durou exatos 41 anos, desde a Constituição de 33 até o Abril de 74. Na altura da publicação do livro de Sena, o próprio Oliveira Salazar (1889-1970) já estava morto e a ditadura sobrevivia junto à guerra colonial no post-mortem de seu principal estadista. 
esteve, em meados do século XVI (provavelmente entre 1567 e 1570, quando enfim volta para Lisboa), a Ilha certamente não era pobre - paupérrimo, pois, era o estado do poeta que, segundo narra um seu amigo Diogo do Couto que lá com ele esteve, encontrou-o "tão pobre que comia de amigos". (CANTO apud MATOS, 2012, p. 93). A escrever o famoso Parnaso de Luiz de Camoens, livro que se perderia para sempre e do qual não ficou um sequer registro, o poeta alimentava-se da sua autoimagem anacronicamente degenerada, como a antever a miséria que dele fariam. Sena constrói um Camões de visão trans-histórica, descrevendo no espaço da poesia (espaço ficcional por excelência) a síntese antropofágica do cadáver que do poeta quinhentista havia sido feito.

Partindo do mesmo esquema apresentado por Sterzi em sua leitura da antropofagia de Oswald de Andrade, poderíamos sugerir o seguinte: Tese Camóes histórico, poeta pobre a pedir no Paço a tença que lhe devem por seus serviços militares no Oriente; Antítese - Camóes mítico, soldado espadachim, defensor da Fé e do Império, brônzeo e monumental, de louros à cabeça; Síntese - Camóes subversivo, transfigurado pela própria poesia, na imbricação entre sua vida e obra. Sena, por assim dizer, antropofagicamente deglute "o símbolo da raça" e nos devolve o poeta em sua dignidade humana. A transgressão operada por este gesto, como vemos, não consiste em negar o lugar de Camóes na cultura portuguesa, mas em redimensionar o seu valor: "Como nau nos baixios que aos Sepúlvedas / deram no amor corte primeiro à vida, / aqui ficou sem nada senão versos.” (SENA, 2013, p. 649). É, afinal, do poeta que se fala, entretanto, nada lhe resta senão sua obra, da qual precisa se retroalimentar para que dela expurgue os inúteis resquícios de mal disfarçada ideologia.

Jazem aqui em lápides perdidas os nomes todos dessa gente que, como hoje os negros, se chegava às rochas, baixava as calças e largava no mar a mal-cheirosa escória de estar vivo. Náo é de bronze, louros na cabeça, nem no escrever parnasos, que te vejo aqui. Mas num recanto em cócoras marinhas, soltando às ninfas que lambiam rochas 
o quanto a fome e a glória da epopeia

em ti se digeriam. (SENA, 2013, p. 650).

O rebaixamento operado por Sena da imagem de Camóes nada tem de depreciativo. A excreção camoniana impóe sobre o poeta a sua inequívoca condição humana e, ao restituir-lhe a humanidade, emparelha-o aos outros tantos cujos nomes jazem em "lápides perdidas", assim como aos negros que hoje repetem o mesmo gesto. Identificando-os a todos, a morte é o sinal que nos permite liar todas as figuras evocadas pelo poema como provedores de matéria em decomposição. $\mathrm{O}$ ininterrupto ciclo da vida e a certeza da finitude são, por fim, o caráter trágico com o qual Sena soube lidar de forma a reconduzir a precariedade da existência em matéria orgânica em contínua metamorfose. A este movimento é igualmente submetida a obra camoniana, que, através dos tempos, mantém-se em transformação para que de seu tempo chegue até nós com um sabor a renovada contemporaneidade.

A digestão de Camóes indica, assim, o modo pelo qual o autor de Exorcismos não só soube reabilitar a figura do poeta quinhentista como aponta um dos mais significativos exercícios de leitura da poesia camoniana. Isto porque o poema em questão, assim como muita de sua obra, nos sugere uma visada muito pertinente ao entendimento dos usos da linguagem poética pelo "Principe dos Poetas do seu tempo". Vida e morte são as molas propulsoras que movem a poesia camoniana e a ambivalência concernente ao seu aspecto criativo/destrutivo é a marca fundamental para a constituição de seu horizonte utópico, o qual, como aprendemos com Sterzi e a antropofagia oswaldiana, resguarda uma intrínseca feição transgressora: "Se a ideologia (...) tem o objetivo de conservar a ordem estabelecida, a utopia, por sua vez, é sempre subversiva - apresenta-se sempre como elemento dissolvente daquela ordem." (STERZI, 2011, p. 442). Trazemos à baila a questão utópica por justamente Camóes, no poema seniano, encontrar-se numa Ilha. Como sabemos, é também em uma "ínsula divina" que se fundamenta a utopia amorosa camoniana. A Ilha dos Amores, construída por Vênus e seu filho Cupido e ofertada como prêmio aos navegantes portugueses, é episódio de importância incontornável, não apenas na diegese d'Os Lusíadas, como para a compreensão da dimensão ética que assume o amor na obra de Camóes. Se, como declara Sterzi, a utopia é essencialmente subversiva, por que haveria de ser a Ilha de Vênus um espa- 
ço de harmonia e apaziguamento como leu e ainda tem lido parte da crítica camoniana? A leitura de Sena para este Camóes, não em uma "Ilha alegre e namorada" (Lus., X, 143), mas em uma ilha pobre onde o poeta deve expurgar as maldiçóes que sofrera em vida e depois da morte, atualiza-o ao fazer da experiência da crise um modo de pôr em contato ambas as produçóes poéticas, a sua e a dele.

Pendendo para as pedras

teu membro se lembrava e estremecia

de recordar na brisa as croias mais as damas,

e versos de soneto perpassavam

junto de um cheiro a merda lá na sombra,

de onde n'alma fervia quanto nem pensavas.

Depois, aliviado, tu subias

aos baluartes e fitando as águas

sonhavas de outra Ilha, a Ilha única (...)

E de zarolho não podias ver

distâncias separadas: tudo te era uma

e nada mais: o Paraíso e as Ilhas,

heróis, mulheres, o amor que mais se inventa

e uma grandeza que não há em nada. (SENA, 2013, p. 650-651).

O deslocamento operado pelo poema em questão relativamente à utopia amorosa da Ilha de Vênus n'Os Lusíadas é flagrante, de modo que, às águas, espaço mítico do imaginário cultural português, é reservada a função de esgoto, onde Camóes mais os negros de hoje e os mortos de ontem depositam seus excrementos. Chegamos a comentar, ainda que muito brevemente, a hipótese de leitura a qual destaca o movimento de escrita poética camoniana como um processo de de-composição. Trata-se de uma perspectivação sobre a linguagem que a compreende enquanto retorno - restituição do sujeito que a experimenta ao estado natural, logo, movimento palingenesíaco que redimensiona os sentidos da morte para uma abertura às metamorfoses da matéria. Se a princípio o rebaixamento de Camóes, a defecar sobre as águas que tanto cantou, sugere-nos a anulação de seu potencial simbólico à estreita negatividade da finitude humana, por outro, é capaz de trazer a lume o poeta transfigurado, 
reconciliado tragicamente com o ciclo da vida, que não esconde ser também ciclo da morte, sem transcendência. Os "versos de soneto" que "perpassavam / junto de um cheiro a merda" poderiam ser lidos não somente como indício deste retorno ao natural, à contínua putrefação e germinação da vida, mas como legítimos movimentos implicados no processo antropofágico de deglutição do objeto cultural detentor de um status hegemônico e, no caso, fase final da digestão, de excreção da matéria fecal (metáfora da miséria em que se encontrava o poeta e da imagem que dele foi feita).

O Camóes que se expurga da vileza dos ricos e de sua real pobreza na Ilha de Moçambique afinal não encontra redenção possível para além de sua mortal condição humana: "o amor que mais se inventa / e uma grandeza que não há em nada” são elementos ofertados por Sena no sentido de se cumprir uma das mais importantes leituras do poeta no século XX. Para Camóes, que reconhecia em matéria poética uma estreita ligação com a atividade amorosa, os deslocamentos de uma atitude que reconhecia em eros uma potência de transformação, a qual seria mesmo tomada como força capaz de emendar a experiência do sujeito no mundo, para o espaço de "uma grandeza que não há em nada”, não devem causar espanto, na medida em que o próprio poeta atestaria os erros e enganos do amor. Helder Macedo (importante estudioso da poesia camoniana), assim como Sena, desconfia deveras da aura neoplatônica com que revestiram Camóes, e o seu interesse em ler esta poesia em sua radical contemporaneidade fica evidente na investida que o ensaísta faz de uma leitura do amor erótico na obra camoniana. O interesse pela realidade do corpo desloca tal visada crítica para o campo da imanência, de modo que a experiência do trágico ganha maior espessura sob esta perspectiva. Sobretudo no que diz respeito a questóes de fé, a poesia camoniana é um desconcertante testemunho da ausência de Deus no mundo, cujo regimento, modernamente, o poeta concentra sobre a própria subjetividade e sua potência desejante. Segue-se a este posicionamento, entretanto, a inevitável errância que do amor leva-o ao desvario e à amargura. No soneto "Correm turvas as águas deste rio", lemos os dolorosamente contemporâneos versos: "Tem o tempo sua ordem já sabida;/ o mundo, não; mas anda tão confuso,/ que parece que dele Deus se esquece." Retirar Deus do mundo, em outras palavras, pode ser compreendido como anular qualquer potencial transcendente para a existência humana, ainda mais se considerarmos que tais palavras saíram de um poeta do século XVI, em um 
Portugal em plena Contrarreforma, para quem a opção de ateísmo estava fora de cogitação. A assombrosa conclusão a que se chega no soneto supracitado é indício inequívoco de um investimento ético da poesia camoniana a partir da incerteza: "Casos, opinióes, natura e uso/ fazem que nos pareça desta vida/ que não há nela mais que o que parece."

Retornando ao poema de Sena, a percepção de "uma grandeza que não há em nada" é o corolário lógico daquele que suspeita não haver na vida "mais que o que parece”. A aparência enquanto limite dos cuidados humanos é, como sabemos da poesia camoniana, um saber provindo da experiência de um sujeito que atribuiu ao amor o meio privilegiado para a laboraçáo, não de uma verdade, mas de verdades, a partir das "várias flamas" em que "variamente ardia”. Os versos finais do texto seniano acenam para aquilo que poderíamos denominar de alegria trágica, e que já na poesia de Camões era marca de uma derrotada busca por contentamento ${ }^{6}$ :

Pousavas n'água o olhar e te sorrias

- mas não amargamente, só de alívio,

como se te limparas de miséria,

e de desgraça e de injustiça e dor,

de ver que eram tấo poucos os melhores,

enquanto a caca ia-se na brisa esbelta,

igual ao que se esquece e se lançou de nós. (SENA, 2103, p. 651).

Este convívio terrível entre o cômico e o trágico, apontado no sorriso aliviado que o Camóes ficcional lança para o mar, é, a meu ver, a mais transgressora das imagens a que Sena reporta o vate quinhentista. Consequentemente, podemos lê-lo como uma renovada figuração utópica que, porém, não

6 Helder Macedo descreve com perícia este perfil camoniano. Em seu texto "Camóes então e agora”, lemos: "A peregrinação registada na sua obra aponta para qualquer coisa de tão indefinível, mas revolucionariamente tâo moderna, quanto é o direito à felicidade na terra. Foi, assim, um poeta mais da dúvida do que da certeza, da ruptura mais do que da continuidade, da experiência mais do que da fé, da imanência mais do que da transcendência, de uma sexualidade indissociável da espiritualidade do amor e, no fim da sua demanda, de uma fragmentação encontrada no lugar da felicidade desejada." (MACEDO, 2010, p. 16). A frágil felicidade que se torna fragmentação é o sinal trágico que observamos em estado de atualização no poema de Sena a que, por ora, nos dedicamos à leitura. 
houve tenção de prestar contas no parnaso. Clément Rosset, em sua Alegria: a força maior, afirma estar "persuadido que a alegria consegue acomodar-se com o trágico, mas ainda e sobretudo, que ela consiste apenas neste e por este acordo com ele." (ROSSET, 2000, p. 25). É justamente a partir da consciência da finitude que uma legítima experiência de gáudio pode se manifestar. Esta perspectiva de estudo não se distancia de algumas recentes leituras realizadas acerca da função desempenhada por Vênus e Baco na utopia amorosa da Ilha dos Amores $^{7}$, de modo que esta passa a poder ser compreendida como um verdadeiro bacanal, na medida em que os prazeres da carne lá experimentados mais se aproximam de um êxtase erótico-dionisíaco do que aquilo que se poderia supor ser um ortodoxo prêmio ofertado a navegantes cristãos. $\mathrm{O}$ veemente erotismo presente na épica e na lírica camonianas será outro importante viés de recuperação desta poesia, sobretudo no que tange aos usos transgressores do corpo e à constituição de uma política de afetos, elementos táo caros à contemporânea poesia portuguesa.

Poeta que não nega a sua linhagem seniana, sobretudo no que diz respeito a um compromisso testemunhal de seu tempo, Manuel de Freitas é um dos principais nomes da mais recente poesia portuguesa. Autor de uma já vasta produção poética, a sua figura é inadvertidamente atrelada ao grupo que ficou conhecido como poetas sem qualidades, título da antologia por ele editada que reunia jovens autores que iniciaram as suas produçóes entre fins do século XX e princípios do XXI. Embora não conste na antologia com seus poemas, Freitas assina o prefácio, que porventura provocou mais burburinhos no meio cultural português do que qualquer poema presente no livro. "O tempo dos puetas" (sic), para além dos ataques certeiros com que alveja alguns canônicos da poesia portuguesa, compreende uma profícua reflexão acerca do que seja ser contemporâneo em um tempo guiado pelo imperativo da ruína e da vida para consumo: "estamos perante o reino do quantitativo, da mercadoria que se assume como tal. Ao homem reificado, cabe um tempo - e também, cada vez mais, um espaço - sem qualidades." (FREITASb, 2002, p. 10).

A leitura mais correta (se pudermos usar o adjetivo) do que queira sig-

7 Sobretudo acerca do personagem de Baco e sua função simbólica n'Os Lusíadas, o extenso trabalho de Luiza Nóbrega, No reino da água o rei do vinho, é exemplar de uma leitura que se concentra, precisamente, no caráter contraditório da narrativa épica, a qual, segundo a autora, se desencadeia como texto trágico-lírico. 
nificar a expressão "sem qualidades" direciona-nos o olhar para aquilo que Freitas diagnostica em seu tempo como consequência da cultura de mercado: a prevalência da quantidade em detrimento da qualidade. Sem aprofundar nas implicaçôes várias que o sema "qualidade" possa implicar, Freitas parece levantar uma questão de valor histórico-cultural, o qual seria obliterado pela economia de mercado na medida em que o livro, mais um produto entre produtos, é apenas "mercadoria que se assume como tal". Todavia, arrisco outra perspectiva de leitura. E, para tanto, parto de nota introdutória ao mesmo prefácio e igualmente assinada por Freitas, em que o autor descreve as circunstâncias de concepçấo da ideia de uma antologia de poetas sem qualidades: "Talvez não seja de todo inoportuno assinalar que nos encontrávamos, nessa tarde cheia de pombas, em pleno largo de Camóes, o poeta português a quem mais qualidades são reconhecidas (até ou sobretudo pelos que nunca o leram)." (FREITASb, 2002, p. 6). A presença de Camóes no contexto de formulação de uma poética que se quer radicalmente contemporânea não é nada inocente. A des-leitura do poeta enquanto monumento (Freitas encontra-se em frente à estátua do vate quinhentista em um espaço de importância poética e histórica na tradição cultural portuguesa) é, como já viemos tratando acerca do poema de Jorge de Sena, o modo pelo qual gostaríamos de compreender uma espécie de gesto antropofágico. Ao criticar as muitas qualidades reconhecidas ao épico de outrora, Freitas, em contrapartida, acena para o declarado desejo de redescobrir um Camóes sem qualidades, descrevendo, consequentemente, um movimento de atualização deste poeta que, para este estudo, muito interessa.

Falamos, há pouco, do interesse desta poesia mais recente pela questão do corpo e suas implicações políticas, sobretudo quanto à ressignificação da negatividade inerente à precariedade da matéria, a qual se manifesta sob a forma da alegria trágica. O reconhecimento deste movimento como gesto antropofágico torna-se ainda mais evidente em um texto de Freitas curiosamente intitulado "Camóes burger".

É conforme. Já lá vão mais de

quatrocentos anos de tal "conversa

fiada” que poucas penélopes encontrou.

Para alguns, doutos e moralíssimos,

o comércio com as musas não era compatível 
com fodas de foder bem dadas, em redondilhas

um pouco maiores do que eles, os necrófagos de serviço. (FREITASa, 2002, p. 45).

"Necrófagos de serviço" chama o eu lírico àqueles tantos leitores que de Camóes fizeram uma imagem cristalizada, inerte, e afinal tâo avessa à espessura de seus versos, que puderam mover estes de Freitas, em legítimo exercício antropofágico. Deslocar o poeta deste estado de conformidade para investir, por exemplo, na sexualidade inerente mesmo a sua obra é agir contra "doutos e moralíssimos", representantes inequívocos de discursos de poder. Em outras palavras, ao ler um Camóes cujo comércio com as musas afinal é compatível "com fodas de foder bem dadas, em redondilhas", Freitas recupera a potencial mobilidade dos versos daquele para quem "bastava o amor somente". Esta mesma acepção da poesia camoniana remete-nos àquilo que Sterzi destaca a respeito da experiência da alegria, que, enfim, não podemos obliterar como horizonte de ação ética para o autor d'Os Lusiadas. A leitura que o ensaísta brasileiro propõe da Tese de Oswald de Andrade, A crise da filosofia messiânica, discute, na esteira das reflexóes de Friedrich Nietzsche, a falência do pensamento católico cristáo e de sua moral opressora, de modo a repensar o ideal parusaico $^{8}$ como utopia. A incerteza quanto à redenção esperada na alegria eterna do Reino dos Céus é substituída pela vivência da alegria no tempo presente, e sempre em vias de acabar. É neste sentido que Sterzi aponta reiteradamente para a máxima retirada do Manifesto Antropofágico de Oswald: "A alegria é a prova dos nove." (ANDRADE, 2011, p. 30). Assumindo o caráter intrinsecamente transgressor da afirmação da alegria é que Sterzi pode reconhecer o princípio da transformação no cerne de uma política dos afetos. No caso do poema de Freitas, o gesto antropofágico lia-se diretamente à ideia de ressignificação da sexualidade inerente ao amor em Camóes, a qual por tanto tempo foi renegada em consideração a neoplatonismos de Petrarcas e Dantes:

8 Parousía, enquanto conceito filosófico que designa a redentora vinda do messias para a Terra, é o termo que Oswald encontra para desestabilizar a ideia de fatalidade implicada na própria esfera do pensamento cristão. Na medida em que o ideal parusaico é concebido como indecidibilidade relativamente à volta de Cristo, a incerteza instaura o terreno possível para a açáo ética no mundo, destituindo a poderosa perspectiva fatalista cristã e restituindo a liberdade histórica. "Contra a inevitabilidade do destino, a parousía é uma promessa que só se enuncia no horizonte de uma permanente indecidibilidade, de um incansável será?” (STERZI, 2011, p. 442). 
"A contraposição da antropofagia ao messianismo marca um deslocamento do tempo da alegria - do futuro para o presente: é aqui e agora que a alegria deve acontecer." (STERZI, 2011, p. 447). Camóes, que tudo sacrificou "só por ver que cousa era viver ledo", decerto concordaria com Oswald e Freitas.

Em registro de deflagrada releitura, lemos ainda no poema em estudo: "Os tempos mudaram, claro (e as vontades foram/ encontrando novos alvos), mas a comédia dos ossos/ veio para ficar, incerta, numa praia/ insigne de enganos e misérias." (FREITAS, 2002a, p. 45). A referência ao translado dos restos mortais de Camóes ${ }^{9}$ é revisitada como comédia sem que da cena seja subtraída a sua inevitável carga de tragicidade. A partir do diálogo com o conhecido soneto "Mudam-se os tempos, mudam-se as vontades", o autor de Game over pode encontrar espaço para, em movimento contrário aos "necrófagos de serviço", posto que conferindo nova vida à obra que revisita, realizar a metamorfose do fantasma camoniano. Os despojos mortais a partir dos quais discursa o sujeito lírico são bastante afins ao que pensa Freitas a respeito de uma poesia sem qualidades, da qual a imagem da morte e dos restos que anunciam a precariedade da existência são elementos recorrentes.

O estado de processamento industrial a que se compara o status alcançado pelo poeta de quinhentos é, afinal, a "ironia fera” de que o sujeito lírico toma partido para expurgar este Camóes fast food de versos "propícios às presidências que tão mal presidem” (FREITAS, 2002a, p. 45), como lemos em passagem do mesmo poema. Há, a meu ver, no descaramento de uma linguagem tão esdrúxula quanto prosaica - de versos como "São gajos novos, ou nem tantos assim,/ místicos do "progresso" em que seus redondos/ cus as-

9 O poema remete ao episódio de exumação da ossada de Luís de Camôes, realizada no ano de 1878. Na altura, os restos mortais do poeta forma desenterrados sob pretexto das comemoraçóes de seu tricentésimo aniversário de morte (1880). A “comédia dos ossos”, a que Freitas alude, aponta para o fato de que Camóes havia sido enterrado em cova rasa, junto de outros tantos anônimos no cemitério da Igreja de Sant'Anna, o que tornaria praticamente impossível a recuperação de seus despojos sem que junto deles não estivessem os ossos de outras pessoas. Após o terremoto de 1755 que, assim como o referido cemitério, destruiu grande parte da cidade de Lisboa, supor que seja plausível encontrar o corpo de Camóes em sua integridade é nada menos que absurdo.

Sobre este tema, também Jorge de Sena escreveu - o seu poema "Camóes dirige-se aos seus contemporâneos" remete à mesma circunstância: "Nada tereis, mas nada: nem os ossos,/ que um vosso esqueleto há-de ser buscado,/ para passar por meu. E para outros ladróes,/ iguais a vós, de joelhos, porem flores no túmulo.” (SENA, 2013, p. 331). 
sentam, isto é, sobre um povo analfabeto e tudo/ que ainda não lê nem sonha a pátria que foi, apenas, pretexto." (FREITAS, 2002a, p. 45) - aquele mesmo riso aliviado do poema de Sena e de anos de forçoso recalque a que foi submetida uma poesia tão afeita aos caprichos do desejo. Em oposição ao mais alto patamar ocupado pelo homem na evolução histórica, a irônica inscrição dos "místicos do 'progresso" (ironicamente inscrito entre aspas) e seus baixos cus assentados sobre um povo que não sabe ler, tema, aliás, tão contemporâneo ao próprio Camóes d'Os Lusíadas e sua amarga consciência de se ver "Cantar a gente surda e endurecida" (Lus., X, 145).

Devoração antropofágica: "Libertar-se do tabu, por sua transformação em totem, é um esforço desde sempre alegre, que só se dá na alegria e pela alegria. A boca que devora é a boca que ri." (STERZI, 2011, p. 446). Em outras palavras, profanar o objeto dedicado à sagração, o que, na concepção de Giorgio Agamben, significa restituir ao uso comum o que foi separado para fins religiosos. No gesto transgressor promovido pelos versos de Sena e Freitas há inequivocamente uma ação profanadora que almeja a construção de uma nova comunidade ledora. É curioso perceber que a ideia de comunidade pode até nós chegar por meio do modernista português José Almada Negreiros, que, a sua maneira, partilha de uma veemente alegria muito afim à antropofágica oswaldiana ${ }^{10}$. Em "Direcção única", ensaio de 1932, Almada expóe uma interessante reflexão de caráter filosófico-literário pautada em uma concepção de mundo regida por complementaridades que, consequentemente, refutam toda e qualquer forma de isolamento. Perpassa pelo texto também aquela mesma consciência trágica da existência que, entretanto, deve ser alegremente devorada junto com tudo que no mundo tem fim: "Hoje, neste admirável século $\mathrm{XX}$, trágico e alegre, a claridade é tanta que podemos ver a imensidade da nossa própria tragédia em toda a sua extensão e domínios (...)" (NEGREIROS, 1997, p. 758-759). Poder ver a tragédia exige-nos um necessário movimento distanciador, um deslocamento no tempo e no espaço para que dela possamos tomar a sua dimensão cômica, ridiculamente sujeita à ruína. E é neste mo-

${ }^{10}$ Curioso é também destacar o fato de que Almada Negreiros, que não desfruta da fama dos portentosos Mário de Sá-Carneiro e Fernando Pessoa, não possui nacionalidade portuguesa. De fato, o poeta e desenhista do modernismo de Orpheu nasceu em Trindade, Sáo Tomé e Príncipe, o que lhe confere um olhar inevitavelmente estrangeiro, marginal. 
vimento de alteridade ${ }^{11}$ que tanto Almada quanto Oswald reconhecem esta potência profanadora, a qual, em matéria de poesia, resultaria em uma nova comunidade ledora, comunidade humana portanto.

Não entraremos no mérito dos estudos de Agamben sobre a ideia de profanação; a sua presença neste trabalho chega, por outro lado, para nos ajudar a pensar a questão da contemporaneidade. No famoso texto "O que é o contemporâneo?”, o ensaísta italiano afirma que

A contemporaneidade, portanto, é uma singular relação com o próprio tempo, que adere a este e, ao mesmo tempo, dele toma distâncias; mais precisamente, essa é a relação com o tempo que a este adere através de uma dissociação e um anacronismo. Aqueles que coincidem muito plenamente com a época, que em todos os aspectos a esta aderem perfeitamente, não são contemporâneos porque, exatamente por isso, não conseguem vê-la, não podem manter fixo o olhar sobre ela. (AGAMBEN, 2009, p. 59).

É interessante notar a urgência por contemporaneidade reivindicada por Freitas no prefácio a Poetas sem qualidades, sobretudo se, acerca deste assunto, buscarmos ver com outros olhos o que seja sem qualidades. Naturalmente, como já assinalamos, a poesia desta geração pode ser lida sob o viés da ausência de qualidades naquilo que nela encontramos de resto da cultura de mercado. Aliás, o interesse por temáticas citadinas e o gosto pela ruína inscrita em uma linguagem que por muitas vezes flerta com o prosaísmo legitimam esta perspectiva de análise. Todavia, creio ser igualmente válida a percepção do que seja sem qualidades como aquilo que é incaracterístico ${ }^{12}$,

11 Oswald claramente declara em seu Manifesto: "Só me interessa o que não é meu. Lei do homem. Lei do antropófago.” (ANDRADE, 2011, p. 27). Almada, por sua vez, é igualmente peremptório: “(...) o indivíduo está tâo longe de si mesmo que para chegar até si tem primeiro que dar a sua volta ao mundo, completa, até ao ponto de partida. // E todo aquele que queira encontrar dentro de si mesmo a sua própria personalidade, ficará romanticamente sozinho no meio das multidóes (...) // O indivíduo nunca pertenceu a si mesmo." (NEGREIROS, 1997, p. 763).

12 Incaracterístico como um Macunaíma à moda lusa. O "herói sem caráter" de Mário de Andrade pode ser entendido como um amálgama das muitas etnias que identificam (?) o brasileiro e que, paradoxalmente, impedem-no de se conformar sob uma única forma fixa. 
informe em termos deleuzianos, posto que insubordinado aos discursos hegemônicos.

Para compreendermos este movimento, a leitura de "Cronofobia" de Freitas pode nos trazer algumas questóes relevantes. Vamos ao poema:

Sou contemporâneo de Villon

e escrevo às vezes a Montaigne,

arguto mas demasiado absorto

no renome e na sabedoria instável

dos seus livros anotados.

Escrevo estas linhas agora

outrora, olhando de frente

o crepúsculo (...)

Corre entretanto o boato de que

Castela se apossou de Portugal

e houve até um poeta obscuro

que preferiu morrer antes disso,

em versos de imponderável beleza.

Não sei. $\mathrm{O}$ vinho cola-se-me uma vez mais

aos lábios, cansados peregrinos do amor,

e um galgo aproxima-se devagar

da mão que nunca lerá José Saramago. (FREITAS, 2007, p. 67).

De fato, a contemporaneidade almejada por este eu lírico apresenta complicações inerentes à própria dissociação de uma perspectiva de tempo cronológico: o tempo deste pueta é outro. O título "Cronofobia” já assinala esta distensão temporal que, em contexto poético, aponta para uma nova ordem histórica, desde que emparelhados, simultaneamente, Montaigne e Saramago, por exemplo. No caso, a distinção valorativa entre estes nomes compóe o quadro daqueles que, segundo diretrizes particulares, fazem parte, ou não, 
da linhagem do sujeito lírico (que não seria despropositado assimilar com o próprio Manuel de Freitas). José Saramago, nobelizado romancista português, certamente um dos maiores escritores de nossa língua no século XX, é destituído do tempo histórico freitasiano, logo, dele não é contemporâneo. Poderíamos aventar algumas possibilidades de leitura desta "mão que nunca lerá José Saramago", mas, possivelmente, a mais plausível funda-se nos pressupostos de que o autor de Ensaio sobre a cegueira não partilha de sua concepção de qual seja a função da poesia - função política que não cede a outras cegueiras, impostas pela cultura de consumo do mercado editorial ${ }^{13}$. Talvez o laureado Saramago tenha, sob a ótica de Freitas, demasiadas qualidades, ou a elas tenha acedido sem pesar as implicaçóes políticas de se assumir como discurso hegemônico no universo literário.

A contemporaneidade reivindicada pelo autor de Game over emerge de um tempo outro, cuja ordem histórica é afirmada pela devoração do passado e, simultaneamente, da aprovação de sua presença. Tal discurso constrói-se sob a égide da crise; a ideia de tradiçáo, neste sentido, é assimilada pela contínua reformulação do passado e por meio de uma destituição do eu como criador original: "Escrevo esta linhas agora/ outrora, olhando de frente/ o crepúsculo (...)". Há como que subliminarmente a referência a Camóes na estrofe que começa pelos versos "Corre entretanto o boato (...)"14, citação que, de maneira curiosa, emparelha o poeta quinhentista com Herberto Helder ("poeta obscuro" ${ }^{15}$ ), assinalando, assim, a ordem histórica de seus contemporâneos. Morrer "em versos de imponderável beleza”, afinal, é a tarefa daquele que em matéria de poesia deseja olhar de frente o espírito de seu tempo - gesto sacrificial por excelência, posto que pela escrita deva se distanciar de si mesmo para

13 Como é sabido, Freitas assume uma postura ambígua relativamente ao já exíguo mercado editorial de poesia, o qual sequer se compara com o vasto universo consumidor de romances do qual Saramago faz parte. Se por um lado é crítico acirrado de uma escrita confeccionada em linha de montagem, por outro joga muito bem com a lei de oferta e procura de seus livros de poesia, estratégia que não se pode considerar, a meu ver, desinteressada.

14 A morte de Camóes precede em poucos meses à derrota de Portugal (e ao consequente desaparecimento de Dom Sebastião) contra os mouros na batalha de Alcácer Quibir, que levaria a sua anexaçáo ao território de Castela. É assombroso pensar que, ao final d'Os Lusiadas, Camóes textualmente incite este mesmo Rei a invadir o Marrocos, em vez de manter colônias tão distantes das terras portuguesas.

15 A referência é feita ao conto homônimo de Herberto publicado na obra Os passos em volta (1963). 
se aproximar daqueles que antes romperam com o próprio eu. Duplo deslocamento (subjetivo e temporal), ou fratura, que condiciona a situação poética e que, ao ver de Agamben, constitui o que chama de contemporaneidade: "O poeta, enquanto contemporâneo, é essa fratura, é aquilo que impede o tempo de compor-se e, ao mesmo tempo, o sangue que deve suturar a quebra." (AGAMBEN, 2009, p. 61).

A obscuridade com que se liam Camões e Herberto ao próprio sujeito lírico do poema de Freitas é também sinal de uma desejosa contemporaneidade, se tivermos em vista outra percepção teórica partilhada por Agamben. Para o ensaísta, "contemporâneo é aquele que mantém fixo o olhar no seu tempo, para nele perceber não as luzes, mas o escuro." E continua ele ainda: “Todos os tempos são, para quem deles experimenta contemporaneidade, obscuros. Contemporâneo é, justamente, aquele que sabe ver essa obscuridade, que é capaz de escrever mergulhando a pena nas trevas do presente." (idem, p. $62-$ 63). Assinalo, por fim, a obscuridade reconhecida no fluxo temporal de poema já citado neste ensaio: "Correm turvas as águas deste rio/ que as do Céu e as do monte as enturbaram;/ os campos florescidos se secaram,/ intratável se fez o vale, e frio". O soneto de Camóes, que recupera a imagética heraclitiana, aponta para a inexorável passagem do tempo e seu destino, tão intratável quanto o vale frio: a morte. Dar discurso ao fluxo inapreensível das horas e à realidade fatídica da finitude é um modo de pôr a linguagem em crise, estender aos seus limites o devir trágico da existência, concebida a partir de uma experiência de mundo desconcertado: "os fementidos Fados já deixaram/ do mundo o regimento, ou desvario."

A impossibilidade de fé que não seja engendrada no seio da incerteza é o que funda a ética da poesia camoniana e o que acena para sua radical contemporaneidade. Os modos pelo quais Sena e Freitas agenciam as suas relaçóes com a poesia de Camóes têm muito que ver com os modos pelos quais cada um deles, particularmente, encontrou para se situar criticamente em seus respectivos tempos históricos. É por meio deste gesto que podem aceder a uma contemporaneidade, ainda que obscura e intratável. Antropofágica ou cronofagicamente (se nos é permitida a reformulação do neologismo freitasiano), a poesia de Camóes é atualizada por poetas que sabem, assim como o épico de outrora, se lançar nas trevas de seu presente para que, enquanto sejam devorados pelo tempo, em uma inversão do mito clássico, porventura possam 
dele se alimentar. Deste modo, os riscos assumidos pela contemporânea poesia portuguesa são o que a mantém sob a iminência de ser, alegre e tragicamente, riscada da história e, ao mesmo tempo, o que pode lhe conferir a breve sobrevida da tradição.

\section{Referências}

AGAMBEN, Giorgio. O que é o contemporâneo? e outros ensaios. Tradução de Vinícius Nicastro Honesko. Chapecó: Argos, 2009.

ANDRADE, Oswald de. Manifesto antropofágico. In. Antropofagia hoje? Oswald de Andrade em cena. ROCHA, João Cezar de Castro; RUFINELLI, Jorge (Org.). São Paulo: Editora É, 2011.

CAMÕES, Luís de. Os Lusíadas. Edição organizada por Emanuel Paulo Ramos. Porto: Porto editora, 1978.

. Rimas. Texto estabelecido e prefaciado por Álvaro Júlio da Costa Pimpão. Coimbra: Atlântida Editora, 1973.

DELEUZE, Gilles. A literatura e a vida. In. Crítica e clínica. Tradução de Pedro Eloy Duarte. Lisboa: Edições Século XXI, 2000.

FREITAS, Manuel de. Game over. Lisboa: \& etc., 2002a.

$\overline{2002 b .}$

. O tempo dos puetas. In. Poetas sem qualidades. Lisboa: Averno,

Portugal 0,1: Poemas de Manuel de Freitas. Rio de Janeiro: Oficina Raquel, 2007.

MACEDO, Helder. Luís de Camóes então e agora. In. outraTravessia - Revista de Literatura $n$ 10. Dossiê Helder Macedo, Dossiê Outra Travessia. Edição organizada por Stélio Furlan. Ilha de Santa Catarina, 2010, p. 15-54.

MATOS, Maurício. Luís de Camóes e Jorge de Sena. In. Investigaçóes camonianas. Manaus: UEA Edições, 2012.

NEGREIROS, José Almada. Direcção única. In. Obra completa. Rio de Janeiro: Nova Aguilar, 1997.

NÓBREGA, Luiza. No reino da água o rei do vinho: Submersão dionisíaca e transfiguração trágico-lírica d'Os Lusíadas. Natal: EDUFRN, 2013.

ROSSET, Clément. Alegria: a força maior. Tradução de Eloisa Araújo Ribeiro. Rio de Janeiro: Relume Dumará, 2000. 
SENA, Jorge de. Poesia 1: Obras completas. Lisboa: Guimarães, 2013.

STERZI, Eduardo. Dialética da devoração e devoração dialética. In. Antropofagia hoje? Oswald de Andrade em cena. ROCHA, João Cezar de Castro; RUFINELLI, Jorge (Org.). São Paulo: Editora É, 2011.

\title{
LUÍS DE CAMÕES IN THE CROSSROADS OF A PORTUGUESE ANTHROPOPHAGY
}

\begin{abstract}
It is known that the notion of anthropophagy, on culture, much exceeds Brazilian modernist question and the literary context in which produced Oswald de Andrade. The anthropophagic lesson achieves a trans-historical dimension that greatly helps us to understand the concept of contemporaneity, as Giorgio Agamben thinks. Thus, this paper seeks to point out the contemporary work of Camóes by the anthropophagic swallowing of the monument made of him - engendered by Portuguese poets of the twentieth and twenty-first centuries, including Jorge de Sena and Manuel de Freitas -, which entails a reading of Camões as a poet.
\end{abstract}

KEY WORDS: Luís de Camões; anthropophagy; contemporaneity.

Recebido em: 04/08/2014 Aprovado em: 13/11/2014 